\title{
Dystopian World and Young Adults in M. T. Anderson's Feed Science Fiction
}

\author{
Leni Marlina \\ State University of Padang, West Sumatra, Indonesia \\ lenimarlina.11@gmail.com
}

\begin{abstract}
Dystopian world in young adults literature can be found in science fiction genre such as M.T. Anderson's Feed (2002). The dystopia in this young adults text reveals that there is no hope anymore on Earth because everything living and beautiful has been dead. In this situation, there is an internet chip called 'feed' implanted into humans' brain. It becomes everything for people and it has taken control over the world. In Anderson's Feed, two teenagers, Titus and Violet, are struggling to find themselves in the world which has been dominated and occupied by technology as well as corporate. This research paper discusses the concept of science fiction with a dystopian world as a genre in children's literature. The aim of this paper is to demonstrate the narrative strategies that are employed to construct the main protagonist, within a dystopian society by using Nikolajeva's model of characterization; and to discuss the readers positioning based on point of view, focalisation and characterization as part of narrative strategies which significantly function in inviting the readers to engage with the narrative as well as to position the readers in young adults text. It is found that the homodiegetic narrator and another focalising agent in Anderson's Feed informs the readers that futuristic universe which is maintained through technological and corporate control will cause the worst effect to humans. By using multiple characters' focalisation, Anderson's Feed situates the implied readers into various and challenging positions.
\end{abstract}

\section{Introduction}

Through this paper, the writer will discuss general concept of science fiction with dystopian world as a genre in young adult literature in M.T. Anderson's Feed (2002); and to demonstrate the narrative strategies at general level, which are employed to construct the main as well as the male protagonist, Titus, within Feed's dystopian world by using Nikolajeva's model of characterization and to discuss the position of implied readers. Characters are people who just happen to live in stories and books. The construction of characters in children's text is usually of prime importance in inviting readers to engage with narrative (Bradford, 2010a:3). The more central a character, the more likely he is to be the character point of view (Kercheval, 1997:77). To understand characters fully, they must be returned to the text (Hendrickson, 2004:267). Therefore, the ways of character being constructed in text will situate the readers into various positions.

Every narrative has subject position and the language of the text positions the implied readers (Bradford 2011a:1). The implied readers are the readers the text aims to reach in the catchment area of text (Bradford, 2011b:3). In addition, the implied reader is frequently addressed with questions, pieces of advice and instructions in narrative voice (Valle, 2008:293). The readers themselves are the most obvious source of interpretive diversity, since each one brings to narratives a different set of experiences and expectations (Wallace, 1991:157). The readers can be positioned to respond a narrative through three main elements: themes, character and plots (Watson, 2006). The readers positioning also can be done through a wide range of techniques such as point of view, focalisation and characterization which have significant function in positioning the readers in children's text.

Nikolajeva (2003:8-10) explains that there are some devices to analyse the characterization. They are character's external description, actions, direct speech, mental representation and narratology. Moreover, to gain meaning through inferred characterization requires that readers go beyond the information provided in the text (Norton, 1992:64). Furthermore, a narrator always influences the character's perception of the objects included situations, actions and persons that gives great significance for characterizations (Nieragden, 2002:686). In brief, a character within a textsuch as science fiction can be constructed from some narrative strategies.

\section{M.T. Anderson's FeedAs Science Fiction (Sf)}

M.T. Anderson's Feed(2002)iscategorized as a science fiction (SF) because it contains an imaginative construction of possible futures (Stapledon, 2002:196).According to Weldes and Tuttle,SF deals with imaginary future and its features can be "awesome machines, bizarre cityscapes, ships for travelling through space, distant 
planets, fantastic wonders created by science and advanced technology, and radical transformation of societies and their inhabitants" (2003). In addition,

Franklin defines SF as "a defining feature of modern culture and society" (2009:23) and Sterling state that SF is a period expression of "a technological, scientific, industrial society" (2009:242). In SF, the characters can set off in a spaceship, or a time machine, or travels through some kind of interdimensional gateway, to arrive in a different world (Stableford, 2009:33).Moreover, the genre of science fiction changes as science and technology change the nature of human existence (Gun, 1998:2). Anderson's Feed has all of the required criteriarequired to be included as a SF. Additionally, Sleator (1996:207) states SF is simply as literature about something that hasnot happen yet, but it mayoccur someday. Correspondingly, Guin (2002:507) explains that the events in SF enable the impliedreaders to compare the events in the future world with the reality at the present time. Besides, SF deals with the effects of change on people in the real world as it can be projected into the future or to distant places; it inserts the readers into a world significantly different from the world of present experience (Gunn, 2002a:vii).

Since the nineteenth century science and technology have become major forces for change, and they have change society in ways that no one had imagined (Gunn, 2002b:1).Moreover, SF intends to entertain the readers by delighting them with eventswhich take place in the future; and by chance, something mentioned in a narrative will occur in real life (Lafferty, 2002:345). In contrary, since the motif of SF is often esoteric, fantastical and implausible, itneeds a little clarificationto suggest that they are anchored to the real world (Lambourne, Michael \& Shortland, 1990).As mentioned above, science fiction is a genre which captures futuristic universes controlled by advanced technology and a kind of radical change compared with the presentsituation.

\section{Dystopian World}

Anderson's Feed is set in dystopian world. A dystopia is a futuristic, imagined universe in which oppressive societal control and the illusionsof bothperfectandimperfectsocietyare maintained by the control of both corporate and technology. Adystopian world is contrary to a utopian world (Sargent, 2006:357).According to Bradford, Mallan, Stephen and McCallum, "dystopian narratives will not typically incorporate the full range of benefits which might flow positive environmental policies, but rather allude to them as absence or loss" (2008:80). Additionally, Marks argue that dystopian texts in general function to prompt thinking, rather than to limit it because "it offers a yardstick by which to measure how humans live now, and where humans as individuals and societies are heading" (2005:236). Moreover, the dystopia narrative functions to transform the ideologies of life in the past to create utopian life in the future as described by Bradford, Mallan and Stephens:

The dystopian turn evident in their plots thus encodes not so much a rejection as a recognition of the past, so enjoining upon young readers a responsibility to transform the ideologies of the past to cultivate for the future more utopian forms of political and material environments (2008b:358).

However, the dystopian world constructed in SF has certain function to positions its readers as explained by Papantonakis (2011:344):

Dystopian texts in SF therefore artfully conceal a political allegory and reveal to their young readers the delusions by which an absolutist government deceives its citizens by making them work slavishly and depriving them of their freedom. This is how awareness is created in the reader of the need to prevent such dystopian conditions.

Furthermore, the dystopian narrative can warn the implied readers about the present society as mentioned by Baccolini (2003:11) that the function of dystopia text is:

...to warn readers about possible outcomes of our presence world and entails an extrapolation of

key features of contemporary society. Dystopia, therefore, is usually located in a negatively deformed future of our own world.

All in all, a dystopian world is imperfect society set in imagined future. It can occur as a metaphor of the present time. The dystopian world in Anderson's Feed meets the criteria of dystopia above.

\section{The Main Protagonist's Characterization and Reading Positioning}

The narration in Anderson's Feed occurs almost chronologically. The chronological arrangement is the most common pattern in children's literature (Lukens, 2005:98). Anderson demonstrates a chronological narration with progressing time in order to make connection between events in the narration. The narrative is begun with Titus's arrivalonthe moon with his friends - Link, Loga, Queenly and Calista. The narrative is continued by Titus' experience before and after the 'disconnected feed' period with his old friends and one new friend, Violet, that took place on the moon and on Earth. Finally, it is ended by an appearing of commercial advertisement on Titus' feed when he was crying losing Violet. Through this chronological event, the implied readers are situated to understand Titus's characterization even though it is quite difficult to understand his motivation within the narrative. I would like to argue that in Feed's dystopian world English is mostly adapted 
for future communication. Anderson's Feed is narrated in a first-person voice which uses slang language, poor grammar, particular terms, and limited vocabulary to place readers into the head of the main character, Titus. The narrative shows that many characters use a lot of terms 'like' as one of terms used children, teenagers, and adults. The same situation also takes places in the present world. In this novel the narrator also functions as a character at the same time. Here the narrator participates in the action of the story but he lets the readers know exactly how the charactersfeel and think. Since the narrator also functions as a character at the same time and remains inside the narrative, the narrator is categorized as homodiegetic one (Nieragden, 2002).

Focalisation has significant role in the text. It is the relation between "visions": the agent that sees, and that which is seen (Bal, 1996:118). It is also a relation between the narrator's report and the character's thoughts. Focalization in children's books may be from the perspective of a child or a young person (McGillis, 2009:257). There are three variables to focalise: temporal, distance and limitation of knowledge (Culler, 1995: 88-89). In Anderson's Feed, Titus and Violet are the most focalising agents among other focalisers. Most of events and places were presented from their perspective. Therefore, the implied readers are positioned during the narrative process to listen voices of Titus and Violet as protagonists. In the beginning of the narrative, the narrator - by using first person point of view - introduces the readers with a young male protagonist who went to the moon at spring break with his friends. Throughout most of human's history, the moon has affected humans' life in 'the same way it has affected the tides' (Bergerac, 2002:79). Nowadays, humans have reached and explored at least a limited part of the moon. In Anderson's Feed, the moon is becoming characters' destination for break after getting tired or bored living on Earth. However, the moon in Anderson's Feed is not always as beautiful as they imagined as narrated by Titus:

We went to the moon to have fun, but the moon turned out to completely suck. We went on a Friday, because there was shit-all to do at home. It was the beginning of spring break. Everything at home was boring. Link Arwaker was like, "I'm so null," and Marty was all, "I'm null too, unit," but I mean we were all pretty null, because for the last like hour we'd been playing with three uninsulated wires that were coming out of the wall (p.3).

Titus as the main protagonist enjoyed his life being controlled and given benefit by feed - a chip implanted in humans' brain. Based on the first point of view and Titus' focalisation the readers will know that the feed worked to give a constant flow of information and advertisements. It was just like the internet and the shopping channel plugged into humans' head, so those people never really had to think for themselves because the feedwould prompt them, find information for them, and suggest that they might want to buy the products. Besides, Titus and his friends focalise thatthe feedenabled everyone to have their own music, play games and enjoyed many other entertainments in their head. It also gave very quick or instant communication, and humans never had to miss anything. Most children were born into this world of instantaneous communication and satellite navigation.

Homodiegetic narrator, Titus, shows the reader that he was amazed with his futuristic life being controlled by the feed. Even during his brief period of disconnection from the feed, Titus still needed it. He said "I missed the feed" (p.39). He liked his life controlled by feed. It seemed that he saw nothing wrong with his "feed world" - the world where humans depended too much on technology, but did not empower their critical thinking. For example in consuming products, Titus and his friends were bombarded by the advertisement of the latest products and they were always persuaded to buy the unnecessary products by the feed so they buy and consume the products finally. Additionally, the voice of narrator and the other characters as focalising agents also tells the readers that the children as well as teenagers were bombarded by trends which come and go in the blink of an eye. This can be seen through one party two of the girls go off to the bathroom "because hairstyles had changed."Everything changes very quickly in this society. Everyone, adult, teen, or child was used to the commercialism of their lives.

As stated by Bradford (2010b:133) that "Feed positions its readers simultaneously to advert to and to critique the processes whereby young people are inducted into consumerism." Therefore, the implied readers are positioned as the 'outsiders' in the Titus' dystopian world; and to question humans' consumerist culture. A trip to the moon changed what Titus knew about his world. He met an amazing girl-Violet, who knew what life was like without the feed. Violet was different from the other teenagers. She got her feed later in life. She was smart. She had a quirky father and had a different outlook on life than Titus and his other friends. She was good in learning, reading, and writing by using a pen with her hand. Titus was completely different to Violet. Titus' ability to read, write and even think for himself had been almost completely obliterated by his the transmitter implanted directly into his brain. Violet was not satisfied with the feed. She wanted to fight it, and invited Titus into her rebellion against technology and corporate control.

Violet focalisesthat she was like all her peers, had a feed in her brain, but she didnot depend too much on the feed like her peers because she received it at a later age. Besides, her parents allowed her to understand what life was without the feed. She was able to actively resist the Feed's classifying abilities through unrelated purchases, thoughts, and viewings. Ironically, it was her ultimate downfall because her sporadic feed activities 
have left her without a clear label causing her feed to malfunction when it was corrupted by a hacker. When school restarted, Titus went through a phase of depression caused by feelings of inferiority to Violet, accentuated by poor marks in school. Noticing this, his parents tried to cheer him up. His parents then bought him a new an upcar (the flying car as the trend vehicle in Feed's world). Titus, Violet, and Titus' father went to car shopping. Violet, the girl who had contrast economic background compares with Titus, thoughtthat Titus wastoo spoiled even though she did not say this explicitly.

Violet asked questions to Titus about the poisoning of the planet, people with lesions, and the way in which the feed insidiously feeds off them. This was a new way of looking at the world for Titus, who had never before questioned his technologically enhanced way of life, hanging out with his shallow, trendy friends. Unfortunately, Titus does not have enough sensitivity to understand the odds things let alone to protest the issues of dystopian world. He just kept silent. In the dystopian society, Violet and Titus's father (in front of Titus) also focalise that there were no forests left, the seas were completely polluted and hair falls out in clumps - which may explain the cover of dystopian world. The planet was dying - there were almost no fish left in the sea, and oxygen factories had replaced the world's wild plant life. Moreover, because of the polluted environment, there were the odd lesions that kept affecting more people. However, the main issue is notenvironment decay; “the real disaster in Anderson's Feed has been the feed itself, which when first available was seen as a wonderful opportunity for children's education" (Braithwaite, 2002:39). In fact, education was run through sound bites only.The narrator focalised that it was hard for Titus to think about those things.

Correspondingly, no one seemed to care about the dystopian society except Violet and his father. Most people were on distracting themselves with feed's shows, movies, commercials and shopping, all of which are turned to the point of inanity. In relation with this condition, Bullen and Parsons (2007:128) state that 'As example of current dystopian text for children Feed reflects the hopes and fears at this historical juncture and it is emblematic of the political consciousness risk society produces.' In another part of narrative, Violet sent Titus a list of things she wanted to do before she died. The first few items represented things she would like to do with Titus such as dancing and going to the mountains. After that, her list became more fantastical, describing an ideal life in which she was free from the feed. She wanted to grow old and had grandchildren with Titus, retire by a lake, and had a dog. The second to last item might be an attack on Titus. Violet said that she wanted to not remember what would actually happen, which included Titus standing by her bed, waiting until he had been there long enough to be a good person. Violet's voice focalises that it was so bad living in the dystopian world, so she wanted to find more meaningful life like she had listed. Thus, the implied readers are invited to see the utopian world as contrasted by Violet's arguments. The utopian world missed by Violet was the natural world without control too much on technology and corporate.

In the narrative of Anderson's Feed, the male young protagonist is characterized as a young adult who does not feel trapped living in the dystopia world, so he seems not struggling to escape. In contrary, the female young protagonist questions the dystopian world. She believes that something is terribly wrong with the society in which she lives. She helps the audience recognizes the negative aspects of the dystopian world through her perspective. The story is all about Titus' encounter and response to an awakened sense of the world around him since he met Violet - the one who protested the dystopian world, but the she was annihilated. When Titus found violet laying on bed with pale body and no signals of feed behind her, it is the closure of narrative. Closure is part of a narrative where the various strands are 'tied up' or 'untangled' (Bradford, 2011c:9). The closure of Feed is available within sub-part the deep and $4.6 \%$ under part 4 (Slumberland). It is toward this moment that the entire narrative has been leading. The closure of Feed positions the readers to thinknot only about the message, but also about the fact that there sounds no hopeful tone at the end, which many believe to be a key ingredient in children's literature.

However, the implied readers are situated to be sympathetic a little bit with what occurs to Titus at the end of narrative. Titus realized and struggled to grasp and understood the need for change in his dystopia world. As Titus finally stood beside Violet, the girl who fought the feed, he knew the need for change and struggled with his own understanding a life with a computer chip thinking for him. As focalised by Titus:

And I whispered, Violet...Violet? There's one story I'll keep telling you. I'll keep telling it.

You're the story. I don't want you to forget. When you wake up, I want you to remember yourself. I'm going to remember. You're still there, as long as I can remember you. As long as someone knows you. I know you so well, I could drive a simulator. This is the story (p.297).

The quotation of narration above demonstrates Titus' ability to genuinely care about something other than what he thought and he wanted; it is his ability to care about something outside of himself. Thus, the implied readers who are those ever experienced the similar problems in different situation will understand that they are not alone. These certain implied readers are situated to understand how to live through risky time. As stated by Campbell (2005:5) that "In a dark world, young adult literature is a beacon of light for teens-books that help them through risky times with wisdom, beauty, and laughter." 
Furthermore, the implied readers are positioned to understand what Titus and his friends as young adult missed as stated by Kerr (2009):

What Titus and friends miss is that the changes to their bodies - the implantation of the feed chips_-disables them both intellectually and physically. ... "Titus's final coming of age is signified by his taking ownership of his own body and mind and exercising free will.

It is clear that Anderson's Feed does not provide the readers 'happily ever after' quality of young adult dystopian novel. The dystopian world set in Anderson's Feed moves from bad to worse. It is unlike other works of young adult dystopian fictions that goes from dystopia to a potential utopia. By the end of the narrative, the implied readers are not left with any character to identify with. The one character that attempted to questions and protested the dystopia is destroyed.

In relation with this, the dystopia world in Anderson's Feed givesno hope for its citizen includes the children as explained by Reber (2005:54-55):

Anderson's Feed leads the reader into the complete darkness of an adult dystopia. The text does not supply the hope, the hope in Anderson's novel lies outside the text, in the readers. The readers are the hopeful element in the hopeless world of Feed because only they remain able to resist the feed in the future. The light may go out in Anderson's novel, but the reader, with enough power and courage, can turn it back on.

The homodiegetic narrator's and his friend's focalisation - Violet - inform the readers that futuristic universe which was maintained through corporate and technological control had caused the worst effects to humans. Dystopian world in Anderson's Feed shows that humans (mostly young adult) depend too much on advanced technology, so they have left behind in critical thinking of themselves as well as the awareness of physical environment. In this case, advance science and technology as well as corporate were more likely to damage the world than to build it. Since SF genre 'challenges the readers to see beyond the concrete universe and to envision other ways of living and alternative mindsets' (Pierce, 1996:180), Feed also can position the implied readers at the similar way. Therefore, the exaggerated worst-case scenario in science fiction such as Anderson's Feed enables the implied readers to make a criticism about a current trend, societal norm, and global issues.

\section{Conclusion}

M.T. Anderson's Feed took place in a not too far distance of future where most of the people of the world were connected to a global network chip through brain implantation, feed. This technology actually was taking over many of the processes of the limbic system to the point where once installed it cannot be removed without killing its host. In one side, the world with advanced technology like feed is just like a utopia or perfect world for children as well as teenagers in the present time. In contrary, Anderson's Feed was set in a dystopian world. The dystopian world without no hope for its protagonists can be found in children's literature generally, and science fictions for young adult particularly. In Anderson's Feed, information, mostly commercials, constantly streamed people's mind through feed. Besides, endless entertainments were at people's fingertips while Earth keeping slowly died. The humans' life became slave of their own technology. In Anderson's Feed, two teenagers, Titus and Violet, were struggling to find themselves in the world which had been dominated and occupied by such technology. Since SF can explain 'today's world and tomorrow's possibilities for young people' (Hughes, 1996:198), Anderson's Feed intends to emphasize of behaviour and actions of young adults in the present which reflects their society. The point of reading this novel is not that it shows the implied readers how things are, but how they could be, and how the readers could look at them.

Correspondingly, in Anderson's Feed, the narrative uses the first person point of view and use focalisation mostly from both its male protagonist (Titus) andfemale protagonist (Violet). By using multiple characters' focalisation, Feed situates the readers' into various positions. Firstly, the implied readers are positions to be antipathetic with the young male protagonist' life style in the dystopian world, but they are also positioned to be sympathetic with the male protagonist's struggle to understand the youngfemale protagonist's ideas of 'living back to nature'. Secondly, dystopia world in SF positions the implied readers to think themselvesabout the consequences of advanced technology as it affects the male and female protagonists differently. Thirdly, the implied readers are encouraged to discover their values and develop the courage necessary to defend their freedom. Finally, the implied readers are also challenged to think what could happen to present technologically-driven society in the not-too-distant future if people continue along the same path in dystopia world. 


\section{Books:}

[1] Anderson, M.T. 2002. Feed. Cambridge, Massachusetts: Candlewick Press.

[2] Baccolini, R. 2003. 'A Useful Knowledge of the Present is rooted in the Past'. Dark Horizons: Science Fiction and the Dystopian Imagination. In R. Baccolini and T. Moylan (eds.). pp. 113-134. New York and London: Routledge.

[3] Bal, M. 1996. 'Focalization'. In S. Onega and J.A.G. Landa (eds.), Narratology. pp. 115-128. New York: Longman.

[4] Bradford, C. 2010a. 'Criticism of Literature for Children'. ALL 702 Criticism of Literature for Children: A Variety of Approaches; Study Guide and Readings. Victoria: Deakin University.

[5] Bradford, C. 2011a. 'Point of View and Focalisation: Module 1'. Narrative Theory: Guide Book. Victoria: Deakin University.

[6] Bradford, C. 2011b. 'Narrative Theory and Children's Literature: Introduction'. Narrative Theory: Guide Book. Victoria: Deakin University.

[7] Bradford, C. 2011c. 'Beginning, Endings, Time, Place: Module 2'. Narrative Theory: Guide Book. Victoria: Deakin University.

[8] Bergerac, C. 2002. 'Commuting to the Moon'. In J. Gunn (ed.), The Road to Science Fiction. Volume 1: from Gilgamesh to Wells. pp. 79-81. USA: Scarecrow Press, Inc.

[9] Bradford, C; K. Mallan; J. Stephen\& R. McCallum. 2008. New World Orders in contemporary Children's Literature: Utopian Transformations. Basingstoke, UK: Palgrave Milan.

[10] Culler, J. 1995. Literary Theory: A Very Short Introduction. London: Oxford.

[11] Franklin, H.B. 2009. 'What is Science Fiction and How It Grew?' In J. Gunn; M. S. Barr \& M. Candelarian (Eds.), Reading Science Fiction. pp. 23-32. England: Palgrave Macmillan.

[12] Guin, U.K.L. 2002. 'Science Fiction as Simile'. In J. Gunn (ed.), The Road to Science Fiction. Volume 3: from Heinlein to Here. pp. 507-510. USA: Scarecrow Press, Inc.

[13] Gunn, J. 1998. The Road to Science Fiction. Volume 6: Around the World. 10 ${ }^{\text {th }}$ Edition. Clarkston, GA: White Wolf Publishing.

[14] ------. 2002a. The Road to Science Fiction. Volume 1: from Gilgamesh to Wells. USA: Scarecrow Press, Inc.

[15] ------. 2002b. The Road to Science Fiction. Volume 2: from Wells to Heinlein. USA: Scarecrow Press, Inc.

[16] Hughes, M. 1996. 'Science Fiction as Myth and Metaphor'. In S. Egoff (eds.), Only Connect: Readings on Children's Literature. $3^{\text {rd }}$ Edition. Ontario, Canada: Oxford University Press.

[17] Kercheval, J.L. 1997. 'Constructing Characters'. Building Fiction. pp. 62-81. Cincinnati, Ohio: Story Press.

[18] Lafferty, R.A. 2002. 'The Future as Metaphor'. In J. Gunn (ed.), The Road to Science Fiction. Volume 3: from Heinlein to Here. pp. 245-348. USA: Scarecrow Press, Inc.

[19] Lambourne, R; S. Michael; M. Shortland. 1990. Close Encounters: Science and Science Fiction. New York: Adam Hilger Publishing Ltd.

[20] Lukens, R. 2005. A Critical Handbook of Children Literature. $7^{\text {th }}$ Edition. Boston: Pearson Education Inc.

[21] Pierce, T. 1996. 'Fantasy: Why Kids Read It, Why Kids Need It'. In S. Egoff (eds.), Only Connect: Readings on Children's Literature. $3^{\text {rd }}$ Edition. Ontario, Canada: Oxford University Press.

[22] Sargent, L.T. 2006. 'Eutopias and Dystopias of Science'. In A. Milner (eds.), Imaging the Future: Utopia and Dystopia. Melbourne: Arena printing and Publishing Pty Ltd.

[23] Sleator, W. 1996. 'What is it About Science Fiction?' In S. Egoff (eds.), Only Connect: Readings on Children's Literature. ${ }^{\text {rd }}$ Edition. Ontario, Canada: Oxford University Press.

[24] Stableford, B. 2009. 'Narrative Strategies in Science Fiction'. In J. Gunn; M. S. Barr \& M. Candelarian (Eds.), Reading Science Fiction. pp. 33-42. England: Palgrave Macmillan.

[25] Stapledon, O. 2002. 'The philosopher of Time and Space'. In J. Gunn (ed.), The Road to Science Fiction. Volume 2: from Wells to Heinlein. pp. 196-199. USA: Scarecrow Press, Inc.

[26] Sterling, B. 2009. 'Science Fiction and the Internet'. In J. Gunn; M. S. Barr \& M. Candelarian (Eds.), Reading Science Fiction. pp. 235-243. England: Palgrave Macmillan.

[27] Tuttle, L. 2003. 'Staking Out the Territory'. Writing Fantasy and Science Fiction. pp. 1-15. London: A \& C Black Publisher.

[28] Wallace. 1991. 'From Writer to Readers'. Recent Theories of Narrative. pp. 152-172. USA: Princeton University Press.

[29] Weldes, J. 2003. 'Popular Culture, Science Fiction, and World Politics'. To seek Out New Worlds.pp. 1-27. England: Palgrave Macmillan.

\section{Journals:}

[30] Bradford, C.; K. Mallan \& J. Stephens. 2008. 'New World Orders and the Dystopian Turn: Transforming Visions of Territoriality and Belonging in Recent Australian Children's Fiction'. Journal of Australian Studies. Vol. 32(3):349-359.

[31] Bradford, C. 2010b. 'Everything must go! Consumerism and Reader Positioning in M. T. Anderson's Feed'. Jeunesse: Young People, Texts, Cultures. Vol. 2(2):128-137.

[32] Braithwaite, E. 2010. 'Post-disaster fiction for young adults: some trends and variations'. Papers. Vol. 20(15):5-19.

[33] Bullen, E. \& E. Parsons. 2007. 'Dystopian Visions of Global Capitalism: Philip Reeve's Mortal Engines and M.T Anderson's Feed'. Children's Literature in Education. Vol. 38:127-139.

[34] Campbell, P. 2005. 'Bearers of Light: The Caring Community'. The Alan Review.(Online). Retrieved in August 2011 from <scholar.lib.vt.edu/ejournals/ALAN/v32n3/v32n3. pdf>.

[35] Hendrickson, L. 2004. 'Reading and Writing Character: Review'. Children's Literature. Vol. 32: 264-269. (Online).Retrieved in September 2011 from <http://dx.doi.org/ 10.1353/ chl. 2004.0013>.

[36] Marks, P. 2005. 'Imagining Surveillance: Utopian Visions and Surveillance Studies'. Surveillance \& Society. Vol. 3(2/3):222239. (Online).Retrieved in September 2011 from <http://www.surveillance-and-society.org/doing.htm>.

[37] McGillis, R. 2009. 'What Is Children's Literature?' Children's Literature Association Quarterly. Vol. 37(3): $256-262$.

[38] Nieragden, G. 2002. 'Focalization and Narration: Theoretical and Terminological Refinements'. Poetics Today. Vol. 23(4):685697. (Online). Retrieved in September 2011 from <http://muse. jhu.edu/journals/poet/summary/v023/23.4nieragden.html>

[39] Nikolajeva, M. 2003. 'Beyond the Grammar of Story, or How Can Children's Literature Criticism Benefit from Narrative Theory?' Children's Literature Association Quarterly. Vol. 28(1):5-16. (Online). Retrieved in September 2011 from <http://muse.jhu.edu/ journals/chq/summary/v028/28.1.nikolajeva.html>.

[40] Norton, D.E. 1992. 'Engaging Children in Literature: Modelling Inferencing of Characterization'. The Reading Teacher. Vol. 46(1):64-57. (Online).Retrieved in September 2011 from 〈http://www.jstor.org/stable/20201012?seq=1>

[41] Kerr, L. 2009. 'Frankenstein's Children: Ethics, Experimentation, and Free Will in Futuristic Young Adult Fiction'. The Alan Review.Vol. 36(3).(E-Journal).Retrieved in September 2011 from <http://scholar.lib.vt.edu/ejournals/ALAN/v36n3/kerr.html>. 
[42] Papantonakis, G. 2011. 'Utopia-Dystopia and Greek Science Fiction for Children'.International Journal of Academic Research. Vol. 3(3):340-346.

[43] Valle, L.V. 2008. 'The Narrative Voice in Roald Dahl's Children's and Adult Books'. Didáctica. Lengua y Literatura. Vol. 20:291308.

Other Related Sources:

[44] Reber, L. 2005. 'Negotiating Hope and Honesty: A Rhetorical Criticism of Young Adult Dystopian Literature'. A Thesis Submitted to the Faculty of Brigham Young University.Watson, J. 2006. 'What's is Reader Positioning?' Online). Retrieved in September 2011 from $<$ http;//johnwatsonsite.com/MyClassNotes/Topics/Reader ...>. 